\title{
PENGARUH KEADILAN ORGANISASI DAN STRES TERHADAP ORGANIZATIONAL CITIZENSHIP BEHAVIOR (OCB) GURU SEKOLAH DASAR NEGERI DI KECAMATAN DUKUHWARU TEGAL, JAWA TENGAH
}

\author{
Halipah* $^{*}$
}

Abstract: The objective research is to obtain information concerning to the effect of organizational justice and stress toward teachers organizational citizenship behavior. The research was conducted by using survey method with path analysis in testing hypothesis. In this research, 92 from 120 teacher of teachers selected random sampling. The research was focused on tree aspect; organizational justice and stress toward teachers organizational citizenship behavior. The data were colected with questionnaire and analyzed with path analysis. Result on the analyisis it is conculaded that (1) there the positive direct effect of organizational justice towards organizational citizenship behavior, (2) there is negative direct effect of stress towards organizational citizenship behavior and (3) ) there is negative direct effect of organizational justice towards stress.

Key Words: organizational citizenship behavior, organizational justice, and stress

\section{PENDAHULUAN}

Peningkatan kualitas pendidikan merupakan suatu proses yang terintegrasi dengan proses peningkatan kualitas sumber daya manusia itu sendiri. Maka pemerintah bersama kalangan swasta bersama-sama telah dan terus berupaya mewujudkan amanat tersebut melalui berbagai usaha pembangunan pendidikan yang lebih berkualitas melalui pengembangan dan perbaikan kurikulum dan sistem evaluasi, perbaikan sarana pendidikan, pengembangan dan pengadaan materi ajar, serta pelatihan bagi guru dan tenaga kependidikan lainnya. Tetapi pada kenyataannya upaya pemerintah tersebut belum cukup berarti dalam meningkatkan kualitas pendidikan.

Guru merupakan bagian dari sumber daya manusia yang memiliki peran sentral dalam menentukan output pendidikan. Peran sentral tersebut terkait dengan tugas guru sebagai pengajar yang bertugas mentransfer ilmu pengetahuan kepada peserta didik. Guru merupakan pihak yang paling memiliki interaksi paling intensif dengan peserta didik, sehingga perannya banyak memberikan pengaruh terhadap cara berpikir, bersikap dan berperilaku peserta didik. Guru juga berperan dalam mendinamisir secara internal dan eksternal organisasi sekolah. Dengan demikian guru memiliki peran penting, sehingga mempunyai tanggung jawab besar dalam mewujudkan tujuan organisasi sekolah. Peran penting tersebut terutama terkait dengan eksistensi guru sebagai salah satu faktor yang ikut menentukan tinggi rendahnya mutu pendidikan.

Sejauh mana kontibusi guru dalam mewujudkan tujuan sekolah ditentukan oleh banyak faktor, salah satunya adalah seberapa besar kecenderungan guru untuk menunjukkan perilaku ekstra perannya,atau biasa disebut OCB. Perilaku ini mengarahkan guru untuk melakukan tindakan-tindakan positif yang menguntungkan organisasi sekolah. OCB antara lain ditunjukkan dengan kesediaan untuk menjalankan tugas-tugas di luar peran utama yang dimilikinya, kemauan untuk menjaga kepentingan organisasi,dan mengambil tanggung jawab yang lebih besar untuk

\footnotetext{
* Guru SD Cenderawasih Jakarta Selatan
} 
memajukan organisasi. Perilaku-perilaku guru seperti itu jelas diperlukan untuk dapat mewujudkan tujuan organisasi sekolah.

Isu-isu yang terkait terhadap rendahnya OCB guru di Kecamatan Dukuhwaru dapat dilihat melalui tiga aspek utama: 1) guru honorer tidak memperoleh perlakuan yang wajar,baik kepegawaian, kesejahteraan, dan perlindungannya, 2) Pembinaan dan pengembangan kompetensi dan karier tidak berkembang, dan 3) Hak guru sering tidak bisa diterima dengan wajar dan tepat waktu. Bertolak dari permasalahan tersebut, peneliti tertarik untuk meneliti secara ilmiah permasalahan ini yang diharapkan OCB guru lebih baik karena program KKG telah dilaksanakan dengan baik.

OCB tidak hanya dipengaruhi oleh keadilan organisasi, tetapi juga dipengaruhi oleh stres. Stres dapat terjadi di organisasi manapun dan penyebabnya dapat berasal dari internal individu yang bersangkutan maupun dari lingkungan organisasi. Penyebab stres yang berasal dari dalam individu antara lain tidak terdapat kecocokan antara tipe kepribadian dengan jenis pekerjaan yang dilakukan. Sedangkan penyebab stres yang berasal dari lingkungan organisasi tempat individu bekerja adalah antara lain berupa tuntutan tugas, gaya kepemimpinan atasan, kejelasan karier, pembagian tugas dan sebagainya. Stres apabila tidak diatasi dengan baik akan dapat menimbulkan gangguan baik secara fisik maupun mental dan pada akhirnya dapat mempengaruhi OCB individu yang bersangkutan.

Berdasarkan uraian di atas, maka penelitian ini mengambil judul: "Pengaruh Keadilan Organisasi dan Stres Terhadap Organizational Citizenship Behavior Guru Sekolah Dasar Negeri di Kecamatan Dukuh Waru, Provinsi Jawa Tengah".

\section{Organizational Citizenship Behavior (OCB)}

Menurut Robbins (2011:60) "OCB is discretionary behavior that is no part of an employee's formal job requirements but that nevertheless promotes the effective functioning of the organization". Perilaku ini cenderung melihat karyawan sebagai makhluk sosial yang menjadi anggota organisasi, dibandingkan sebagai makhluk individual yang mementingkan diri sendiri.

Coulquit, LePine dan Wesson (2009:43-44) mengatakan,"citizenship behavior is defined as voluntary employee acttivities some specific examples that may or may not be rewarded but that contribute to the organization by improving the of it". Dengan kata lain dikatakan bahwa perilaku kewarganegaraan didefinisikan sebagai kegiatan sukarela yang dilakukan karyawan yang tidak mengharapkan imbalan yang mungkin atau mungkin tidak dihargai, tetapi yang berkontribusi terhadap meningkatnya suatu organisasi.

Organ dalam Luthans (2008:251) mengatakan" OCB as individual behavior that is discretionary, not directly or explicity recognized by the formal reward system, and that in the aggregate promotes the effective functioning of the organization". Seseorang yang memiliki perilaku warga dalam organisasi bebas memilih, tidak diatur secara langsung atau ekplisit oleh sistem penghargaan formal, dan bertingkat mempromosikan fungsi organisasi yang efektif.

Kinicki dan Kreitner (2008:165) mengatakan, "organisational citizenship behaviors consist of employee behavior that are beyond the call of duty" Pernyataan ini menyatakan perilaku warga organisasi yang berada di luar panggilan tugas. Perilaku tersebut tidak diharuskan oleh persyaratan peran atau deskripsi jabatan sebagai pilihan personal.

Menurut Luthans (2008:251) OCB memiliki berbagai bentuk yaitu pertama altruisme (altruism) yaitu perilaku membantu karyawan yang lain tanpa ada paksaan pada tugas yang berkaitan erat dengan operasi-operasi organisasional misalnya 
membantu saat rekan kerja tidak sehat. Kedua tanggung jawab (councientiousness) yaitu berisi tentang kinerja dari prasyarat peran yang melebihi standar minimum misalnya lembur untuk menyelesaikan proyek. Ketiga kepentingan umum (civic virtue) yaitu menunjukkan partisipasi sukarela dan dukungan terhadap fungsi-fungsi organisasi baik secara profesional alamiah misalnya rela mewakili perusahaan untuk program bersama. Keempat sikap sportif (sportsmanship) yaitu berisi tentang pantangan-pantangan membuat isu-isu yang merusak meskipun merasa jengkel misalnya ikut menanggung kegagalan proyek tim yang mungkin akan berhasil dengan mengikuti nasehat anggota. Kelima sopan (courtessy) adalah perilaku meringankan problem-problem yang berkaitan dengan pekerjaan yang dihadapi orang lain misalnya memahami dan berempati walaupun saat dikritik.

Ivancevich, Konospaske dan Matteson (2008:62) mengatakan, " the company's success and reputation were built by its leaders and employees who constantly pushed the limits to achieve higher levels of perfomance". Keberhasilan dan reputasi perusahaan dibangun oleh pemimpin dan karyawan yang secara konstan berusaha keras mencapai tingkat kinerja yang yang lebih tinggi.

Berdasarkan uraian di atas dapat disintesiskan OCB adalah perilaku yang baik yang dilakukan seseorang yang berdasarkan kesukarelaan dan di luar peran utamanya sebagai pegawai yang dapat memberikan kontribusi positif bagi perkembangan dan efektifitas organisasi serta dilakukan secara suka rela tanpa mengharapkan penghargaan atau reward tertentu dan efektif bagi kemajuan organisasi dengan indikator: altruisme, kesadaran, sportifitas, kesopanan, dan kebajikan.

\section{Keadilan Organisasi}

Greenberg dan Baron dalam Colquitt (2009:546) mendefinisikan keadilan organisasi sebagai "people's perception of fairness in organizations, consisting of perceptions of how decisions are made regarding the distribution of outcome and the perceiveid fairness of those outcomes themselves." Keadilan merupakan kejujuran yang dirasakan dari sebuah kewenangan mengambil keputusan.

Sedangkan Schultz dan Schultz (2006:232) mendefinisikan keadilan organisasi sebagai "how fairly employees perceive themselves to be treated by their company". Keadilan organisasi adalah seberapa adil karyawan merasakan dirinya diperlakukan oleh perusahaan. Sementara Ivancevic,Konopaske dan Matteson (2005:153) mengartikan keadilan organisasi sebagai "the degree to which individuals feel fairly treated at the workplace." Pengertian ini memberikan makna sejauh mana individu diperlakukan secara adil di tempat kerja.

Jenifer (2008:567) mengatakan bahwa," a theory about work motivation that focuses on employee's perceptions of the fairness of their work outcomes and inputs". Persepsi pegawai tentang kejujuran yang menyeluruh tentang organisasinya, diperkenalkan sebagai penentu penting dari motivasi, sikap, dan perilaku karyawan.

Selanjutnya menurut Robbins (2009:258) mengatakan," an overall perception of what is fair in the workplace, composed of distributive, procedural, and interactional justice". Keadilan organisasi merupakan persepsi menyeluruh tentang apa yang jujur di tempat kerja mereka. Salah satu bagian dari kunci dari keadilan adalah persepsi individu tentang keadilan itu sendiri. Dengan kata lain di bawah keadilan organisasi, kejujuran atau kesetaraan bisa menjadi hal yang subyektif dan hal itu terletak dalam persepsi orang apa yang seseorang bisa lihat sebagai sesuatu yang tidak jujur, yang lainnya bisa melihatnya sebagai sesuatu yang sangat tepat. 
Colquitt (2009:226) menyatakan bahwa" employees can judge the fairness of an authority's decision making along four dimentions: distributive justice, procedural justice, procedural justice, interpersonal justice, and informational justice". Ada empat dimensi yang dapat digunakan karyawan untuk menilai kejujuran pemegang kewenangan dalam mengambil keputusan.Keempat dimensi itu adalah (1) keadilan distributif,(2) keadilan prosedural,(3) keadilan interpersonal, dan (4) Keadilan informasional.

Robbins (2009:259) mengemukakan bahwa, "two keys elements procedural justice are proces control and explanations. Process cntrol is the opportunity to present your point of view about desired outcomes to decision makers. Explanations are clear reasons management gives for the outcome. Thus, for employees to see a process as fair, they need to feel they have some control over the outcome and that they were given an adequate explanation about why the outcome occured. It's also important that a manager is consistent, is unbiased, makes decisions based on accurate information, and is open to appeals. Ada dua elemen kunci keadilan prosedural yakni kontrol proses dan penjelasan (explanation). Kontrol proses adalah peluang untuk menghadirkan satu titik pandangan tentang hasil-hasil yang diinginkan kepada pengambil keputusan. Sedangkan penjelasan adalah alasan-alasan yang jelas tentang hasil yang diberikan manajemen kepada seseorang.Untuk melihat sebuah proses yang jujur pegawai harus merasakan bahwa mereka memiliki beberapa kontrol di luar hasil dan merasakan bahwa mereka diberikan penjelasan yang tepat tentang mengapa hasil seperti itu muncul. Hal penting dalam keadilan prosedural adalah bahwa pimpinan harus konsisten, tidak bias, membuat keputusan berdasarkan informasi yang akurat dan terbuka untuk dilakukan banding.

Jenifer (2008:171) menyatakan, "procedural justice is concerned with the perceived fairness of the procedures used to make decisions about the distribution of outcomes. It is not concerned about the actual distribution of outcomes. Procedural decisions pertain to how perfomance levels are evaluated, how grievances or disputes are handled, and how outcomes are distributed. Employees'perceptions are of fundamental importance for procedural justice. That is, employees'reactions to procedures depend on how fair they perceive the procedures to be rather than how fair they actually are." Keadilan prosedural tidak berkenaan dengan distribusi yang sebenarnya tentang hasil-hasil. Keputusan prosedural berhubungan dengan bagaimana tingkatan kinerja dievaluasi,bagaiman keluhan atau perselisihan diselesaikan, dan bagaimana hasil-hasil di- distribusikan.

Berdasarkan konsep yang dijelaskan di atas, maka keadilan distributif adalah kesetaraan yang dirasakan saat mendapatkan hasil-hasil dalam melaksanakan tugas di organisasi sesuai kontribusi yang diberikan terhadap organisasi yang dapat dilihat dari aspek (1) kelayakan dalam perlakuan, (2) kesamaan dalam pendistribusian tugas, dan (3) kelayakan dalam pemenuhan kebutuhan.

\section{Stres}

V.G Kondalkar (2009:114) menyatakan bahwa stres adalah, "stress may be defined as a pattern of emotional and physiological reactions in response to demands from internal or external sources". Kondalkar menyebutkan bahwa stres dapat didefinisikan sebagai pola reaksi psikologis dan emosional sebagai respon terhadap tuntutan dari dalam diri sendiri maupun dari luar.

Pendapat yang sama dinyatakan oleh John schermerhorn, et.al (2010:37), "stress is tension from extraordinary demands, constraints, or opportunities". Stres adalah tegangan yang terjadi karena tuntutan dan permintaan yang luar biasa, desakan, ataupun peluang. Selanjutnya, John schermerhorn, Jr. James G. hunt, dan Richard N. Osborn dan 
Maria (2010:38) juga menyatakan, "constructif stress, eutress is stress that has a positive impact on both attitudes and performance. Destructive stress, distress is a negative impact on both attitudes and performance". Pendapat ini menyatakan bahwa tidak semua stres berakibat buruk pada perilaku kerja yang dihasilkan seseorang. Terkadang stres mengakibatkan seseorang menghasilkan perilaku kerja positif, hal ini disebut eutress.

Menurut John A. Wagner and John R. Hollenbeck (2010:49), "stress is an unpleasant emotional state that results when someone is uncertain of his or her capacity to resolve a perceived challenge to an important value". John A. Wagner and John R. Hollenbeck mengemukakan bahwa stres adalah keadaan emosional yang tidak menyenangkan sebagai akibat dari ketidakpastian yang dialami seseorang dalam kapasitasnya menghadapi tantangan untuk nilai yang dianggap penting. Hampir sama dengan pendapat - pendapat sebelumnya bahwa stres adalah respon emosional terhadap stimulasi tertentu, tetapi John A. Wagner and John R. Hollenbeck menggaris bawahi stres sebagai respon emosi yang kurang menyenangkan dalam menghadapi tantangan. Selanjutnya menurut Colquitt, LePine \& Wesson (2009:142-143) menyatakan, "stress is defined as a psychological response to demand for which there is something at stake and coping with those demands taxes or exceeds a person's capacity or resource." Stres didefinisikan sebagai respon psikologis seseorang terhadap sesuatu tuntutan orang-orang yang melebihi kapasitas dan kemampuannya. Inti dari pandangan Colquitt, LePine dan Wesson adalah respon seseorang secara psikologis dalam menghadapi permasalahan yang terjadi baik yang berhubungan dengan sesamanya maupun dengan lingkungan di sekitarnya.

Stres menurut Colquitt, LePine dan Wesson (2009:156): "therefore negative consequences to the body occur even with the more mundane stressors that most of as face in our lives. Those negative consequences come in three varieties: physiological strains, psychological strains and behavioral strains. Colquitt, LePine dan Wesson mengemukakan, ketegangan atau konsekuensi negatif dapat menyebabkan terjadinya stres dalam kehidupan. Konsekuensi negatif atau ketegangan terdiri dari tiga jenis yaitu ketegangan fisiologis, ketegangan psikologis dan ketegangan perilaku.

Dari uraian di atas, dapat disintesiskan stres adalah keadaan emosional individu yang bersifat negatif secara fisik, psikologis, kognitif, dan perilaku dengan indikator (1) gejala fisik, (2) gejala psikologis (3) gejala kognitif . (4) gejala perilaku. 


\section{METODE PENELITIAN}

Penelitian ini dilaksanakan kepada guru SD Negeri Dukuh Waru, Jawa Tengah. Penelitian ini dilaksanakan selama 4 (empat) bulan, mulai bulan April 2015 s.d Juni 2015. Metode yang digunakan dalam penelitian ini adalah survey dengan menggunakan teknik kausal. Populasi adalah guru SD Negeri Dukuh Waru, Jawa Tengah yang berjumlah 120 pegawai dengan jumlah sampel sebanyak 92 guru. Data yang dikumpulkan dalam penelitian dijaring melalui kuesioner yang berupa skala penilaian (rating scale) dengan sebaran skor antara 1 sampai dengan 5. Selanjutnya dilakukan uji coba intrumen untuk menentukan butir-butir instrumen yang valid dan reliabel. Teknik analisis data dilakukan dengan statistika deskriptif dan statistika inferensial dengan terlebih dahulu melakukan uji prasyarat analisis yaitu normalitas populasi dan analisis regresi.

\section{HASIL DAN PEMBAHASAN}

\section{Pengaruh Keadilan Organisasi terhadap Organizational Citizenship Behavior}

Hasil penelitan ini menunjukkan bahwa keadilan organisasi memberikan pengaruh positif secara langsung terhadap organizational citizenship behavior. Besarnya pengaruh tersebut ditunjukkan oleh koefisien korelasi 0,443 dan koefisien jalur 0,309. Hal ini menujukkan bahwa keadilan organisasi dapat meningkatkan organizational citizenship behavior guru.

Hasil penelitian ini sejalan dengan pendapat Ivancevich et al (2005:153)., yang menyatakan, "procedural justice has been shown to have a positive impact on a number o affective and behavioral reactions. These include: organizational commitment, intent to stay with organization, organizational citizhenship, trust in supervisor, satisfaction with decision outcome, work effort, performance". Keadilan prosedural memiliki efek positif terhadap perilaku. Termasuk di dalamnya komitmen organisasi, kepercayaan pada atasan, kepuasan terhadap hasil keputusan, usaha kerja dan kinerja.

Hal senada juga dinyatakan oleh George dan Jones (2008:174), “organizational justice has been found to be positively associated with job satisfaction, organizational commitment, job perfomance, and organizational citizenship behavior and negatively associated with absenteeism and turnover intentions. Keadilan organisasi berpengaruh secara positif terhadap kepuasan kerja, komitmen organisasi, prestasi kerja, dan perilaku kewarganegaraan organisasi dan negatif terkait dengan tingkat ketidakhadiran dan turnover.

Menurut Gibson (2009:152), "...as equity theory has shown predicted effect for both organizational citizenship (going beyond the call of duty) and attitudes toward tasks and work groups."...sebagai teori keadilan telah menunjukkan adanya pengaruh negatif terhadap kewarganegaraan organisasi (melampaui panggilan tugas) dan sikap terhadap membangun tugas dan kelompok kerja. Coulquitt, LePine dan Wesson (2009:43-44) mengatakan,"citizenship behavior is defined as voluntary employee acttivities some specific examples that may or may not be rewarded but that contribute to the organization by improving the of $i t^{\prime \prime}$. Dengan kata lain dikatakan bahwa perilaku kewarganegaraan didefinisikan sebagai kegiatan sukarela yang dilakukan karyawan yang tidak mengharapkan imbalan yang mungkin atau mungkin tidak dihargai, tetapi yang berkontribusi terhadap meningkatnya suatu organisasi. Organ dalam Luthans (2008:251) mengatakan " OCB as individual behavior that is discretionary, not directly or explicity recognized by the formal reward system, and that in the aggregate promotes the effective functioning of the organization". Seseorang yang memiliki perilaku warga dalam organisasi bebas memilih, tidak diatur 
secara langsung atau ekplisit oleh sistem penghargaan formal, dan bertingkat mempromosikan fungsi organisasi yang efektif. Demikian pula Kinicki dan Kreitner (2008:165) mengatakan, "organisational citizenship behaviors consist of employee behavior that are beyond the call of duty" Pernyataan ini menyatakan perilaku warga organisasi yang berada di luar panggilan tugas. Perilaku tersebut tidak diharuskan oleh persyaratan peran atau deskripsi jabatan sebagai pilihan personal. Menurut Luthans (2008:251) OCB memiliki berbagai bentuk yaitu pertama altruisme (altruism) yaitu perilaku membantu karyawan yang lain tanpa ada paksaan pada tugas yang berkaitan erat dengan operasioperasi organisasional misalnya membantu saat rekan kerja tidak sehat. Kedua tanggung jawab (councientiousness) yaitu berisi tentang kinerja dari prasyarat peran yang melebihi standar minimum misalnya lembur untuk menyelesaikan proyek. Ketiga kepentingan umum (civic virtue) yaitu menunjukkan partisipasi sukarela dan dukungan terhadap fungsi-fungsi organisasi baik secara profesional alamiah misalnya rela mewakili perusahaan untuk program bersama. Keempat sikap sportif (sportsmanship) yaitu berisi tentang pantangan-pantangan membuat isu-isu yang merusak meskipun merasa jengkel misalnya ikut menanggung kegagalan proyek tim yang mungkin akan berhasil dengan mengikuti nasehat anggota. Kelima sopan (courtessy) adalah perilaku meringankan problem-problem yang berkaitan dengan pekerjaan yang dihadapi orang lain misalnya memahami dan berempati walaupun saat dikritik. Dengan demikian, ketepatan dalam keadilan prosedural yang dirasakan seseorang, akan mengakibatkan peningkatan OCB.

\section{Pengaruh Stres terhadap Organizational Citizenship Behavior}

Hasil penelitan ini menunjukkan bahwa stres memberikan pengaruh positif secara langsung terhadap organizational citizenship behavior. Besarnya pengaruh tersebut ditunjukkan oleh koefisien korelasi -0,455 dan koefisien jalur -0,330.

Hasil penelitian ini sejalan dengan pendapat Jhon W.Slocum,Jr dan Don Hellriegel (2009:201), "the effects of work stress have important implications for organizational behavior and organizational effectiveness. We examine some of these effects in terms of health,perfomance, and job burnout. Menurutnya, efek stress kerja memiliki implikasi penting terhadap perilaku organisasi dan keefektifan organisasi. Mereka sudah menguji efek dari stres kerja tersebut yang berkaitan dengan kesehatan, prestasi, dan berhenti dari pekerjaan.

Schermerhorn dan kawan-kawan (2010:338) berpendapat, "to much stress can overload and break down a person's physical and mental systems resulting in absenteeism, turnover, errors, accidents, dissastifaction, reduced perfomance, unethical behavior, and even ilness. Terlalu banyak stres dapat membebani terlalu berat dan dan menurunkan fisik dan sistem mental seseorang, yang mengakibatkan ketidakhadiran, pengunduran diri, kesalahan, kecelakaan, ketidakpuasan, berkurangnya prestasi, perilaku tak pantas, dan bahkan penyakit."...other aspect of the work setting, or personal and nonwork situations, stressor can influence our attitudes, emotions and mood,behavior, job perfomance, and even health" (Schermerhorn dan kawan-kawan, 2010:338). Aspek lain dari lingkungan kerja, atau situasi pribadi dan di luar pekerjaan dapat mempengaruhi sikap kita, emosi dan suasana hati, perilaku,kinerja,dan bahkan kesehatan.

Dalam hal ini Robbins (2009:495) mengemukakan bahwa" stress reactions can lead to increased, sickness, absences, lower concentration on job, and lower creativity." Reaksi stress dapat menyebabkan peningkatan, penyakit, absensi, konsentrasi yang lebih rendah pada pekerjaan, dan kreativitas yang rendah. John schermerhorn, et.al (2010:37) 
menjelaskan, "stress is tension from extraordinary demands, constraints, or opportunities". Stres adalah tegangan yang terjadi karena tuntutan dan permintaan yang luar biasa, desakan, ataupun peluang. Selanjutnya, John schermerhorn, Jr. James G. hunt, dan Richard N. Osborn dan Maria (2010:38) juga menyatakan, "constructif stress, eutress is stress that has a positive impact on both attitudes and performance. Destructive stress, distress is a negative impact on both attitudes and performance". Pendapat ini menyatakan bahwa tidak semua stres berakibat buruk pada perilaku kerja yang dihasilkan seseorang. Terkadang stres mengakibatkan seseorang menghasilkan perilaku kerja positif, hal ini disebut eutress.

Menurut John A. Wagner and John R. Hollenbeck (2010:49), "stress is an unpleasant emotional state that results when someone is uncertain of his or her capacity to resolve a perceived challenge to an important value". Stres adalah keadaan emosional yang tidak menyenangkan sebagai akibat dari ketidakpastian yang dialami seseorang dalam kapasitasnya menghadapi tantangan untuk nilai yang dianggap penting. Dengan demikian, peningkatan stres dapat mengakibatkan penurunan OCB seseorang.

\section{Pengaruh Keadilan Organisasi terhadap Stres}

Hasil penelitan ini menunjukkan bahwa keadilan organisasi memberikan pengaruh positif secara langsung terhadap stres. Besarnya pengaruh tersebut ditunjukkan oleh koefisien korelasi -0,406 dan koefisien jalur -0,406. Hasil penelitian ini sejalan dengan pendapat Steven L. McShane dan Mary Ann Von Glinovw (2008:240) keadilan organisasi mempunyai pengaruh yang kuat terhadap stres" procedural justise strongly influences a person's emotional and motivation."

Ivancevich, Konopaske, dan Matteson (2005:125) menyatakan, "prosedural justise has been shown to have a positive impact on a number of affective and behavioral reactions." Selanjutnya pemahaman tentang pengaruh keadilan organisasi terhadap stres menurut Jenifer (2008:174), "perceptions of organizational justice can have widespread ramifications for employee motivation, attitudes, and behaviors." Persepsi keadilan organisasi dapat memiliki konsekuensi luas untuk motivasi karyawan, sikap, dan perilaku.

Keadilan dalam organisasi dapat mendorong munculnya berbagai sikap dan perilaku dari orang yang mempersepsinya. Seseorang yang merasa dirinya diperlakukan secara adil, maka akan bersikap positif, seperti memiliki semangat yang kuat untuk mematuhi aturan organisasi, mau membantu rekan kerja, dan melakukan kegiatan yang bermanfaat bagi organisasi. Schultz dan Schultz (2006:232) mendefinisikan keadilan organisasi sebagai "how fairly employees perceive themselves to be treated by their company". Keadilan organisasi adalah seberapa adil karyawan merasakan dirinya diperlakukan oleh perusahaan. Sementara Ivancevic, Konopaske dan Matteson (2005:153) mengartikan keadilan organisasi sebagai "the degree to which individuals feel fairly treated at the workplace." Pengertian ini memberikan makna sejauh mana individu diperlakukan secara adil di tempat kerja. Stres menurut Colquitt, LePine dan Wesson (2009:156): "therefore negative consequences to the body occur even with the more mundane stressors that most of as face in our lives. Those negative consequences come in three varieties: physiological strains, psychological strains and behavioral strains. Colquitt, LePine dan Wesson mengemukakan, ketegangan atau konsekuensi negatif dapat menyebabkan terjadinya stres dalam kehidupan. Konsekuensi negatif atau ketegangan terdiri dari tiga jenis yaitu ketegangan fisiologis, ketegangan psikologis dan ketegangan perilaku. Dengan demikian ketepatan dalam keadilan organisasi akan mengakibatkan penurunan stres. 


\section{PENUTUP}

Kesimpulan: (1) Keadilan organisasi berpengaruh positif langsung terhadap organizational citizenship behavior. Artinya ketepatan keadilan organisasi mengakibatkan peningkatan organizational citizenship behavior guru Negeri Dukuh Waru, Jawa Tengah, (2) Stres kerja berpengaruh negatif langsung terhadap organizational citizenship behavior. Artinya, penurunan stres mengakibatkan peningkatan organizational citizenship behavior guru Negeri Dukuh Waru, Jawa Tengah, (3) Keadilan organisasi berpengaruh negatif langsung terhadap stres. Artinya, ketepatan keadilan organisasi mengakibatkan penurunan stres kerja guru Negeri Dukuh Waru, Jawa Tengah

Saran: Pertama, saran untuk kepala sekolah. Kepala sekolah sebagai pemimpin diharapkan dapat berlaku adil kepada semua guru. Perlakuan yang adil mengembangkan pengaruh dan persepsinya yang lebih positif terhadap organisasi tersebut. Kedua, saran untuk kepala sekolah selaku pimpinan, Terkait dengan pembentukan keadilan organisasi memberikan kesejahteraan kepada guru honorer, pembinaan dan karier guru sehingga OCB guru menjadi meningkat.

\section{DAFTAR RUJUKAN}

Coulquitt, Jasson A., Jeffrey A. LePine and Michael J.Wesson. Organizational Behaviour: Improving Perfomance and Commitment in the Workplace. New York: McGrawHill/Irwin,2009.

George, Jennifer M. \& Gareth R. Jones. Understanding and Managing Organizational Behavior. New Jersey: Pearson Prentice Hall.,15 th Edition, 2008.

George, Jennifer M. \& Gareth R. Jones. Understanding and Managing Organizational Behavior. New Jersey: Pearson Prentice Hall.,15 th Edition, 2008.

Gibson et.al., Organizations Behavior, structure, Procesesses. New York: McGrraw-Hill international Edition, 2009.

Ivancevic, J. M., R. Konopaske, dan M.T Matteson. Organizational Behavior and Management. New York: McGraw-Hill Company, 2005.

Kinicki, Angelo and Robert Kreitner. Organizational Behavior : Key Concepts, skills and Best Practices. New York: McGraw-Hill/Irwin, 2008.

Kondalkar, V.G. Organization Development. New Delhi: New Age International, 2009.

Luthans, Freds. Organizational Behaviour. New York: McGraw-Hill/Irwin, 2008.

McShane, Steven. L. dan Mary Ann Vonn Glinov. Behavior: Organizational Emerging Realities For The Workplace Revolution. New York: McGraw-Hill/ Irwin, 2008.

Robbins, Stephen P. \& Timothy A. Judge. Organizational Behaviour. New Jersey: Pearson Educational Inc., 13th Edition,2009. 
Organizational Behaviour. New Jersey: Pearson Education, Inc., 2011.

Schermerhorn, John R. et, al., Organizational Behavior. USA: John Wiley \& Son, 2010.

Schultz, D. dan S.E Schultz. Psychology \& Work Today. New Jersey: Pearson Education Inc, 2006.

Slocum, Jhon W., Jr dan Don Hellriegel. Principles of Organizational Behavior. South Western: Cengage Learning, 2009. 